Article

\title{
Synthesis and Conformational Study of a Novel Macrocyclic Chiral(Salen) ligand and its Uranyl and Mn Complexes
}

\author{
Maria E. Amato, Francesco P. Ballistreri, Andrea Pappalardo, Gaetano A. Tomaselli * \\ and Rosa M. Toscano \\ Dipartimento di Scienze Chimiche, Università di Catania, Viale Andrea Doria 6, Catania 95125, Italy; \\ E-Mails: eamato@unict.it (M.E.A.); fballistreri@unict.it (F.P.B.); andrea.pappalardo@unict.it (A.P.); \\ rmtoscano@unict.it (R.M.T.)
}

* Author to whom correspondence should be addresses; E-Mail: gtomaselli@unict.it.

Received: 21 December 2009; in revised form: 20 January 2010 / Accepted: 2 March 2010 / Published: 9 March 2010

\begin{abstract}
A novel chiral macrocyclic ligand incorporating a chiral salen moiety into a framework containing two biphenyl units was synthesized. Structural properties and conformational aspects of the free ligand and an $\mathrm{UO}_{2}$ complex were studied by using NMR spectroscopy in solution and MM calculations. The Mn(III) complex was tested as catalyst in enantioselective oxidation of prochiral unfunctionalized olefins to the corresponding optically active epoxides under very mild conditions.
\end{abstract}

Keywords: macrocyclic chiral ligand; salen; enantioselectivity; epoxidation

\section{Introduction}

The successful design, synthesis and use of molecules capable of the selective recognition of other species is of great interest in catalysis, separations, enzyme functions and other fields involving molecular recognition [1]. Chiral salen-metal complexes are currently recognized versatile, practical and efficient catalysts for a large number of asymmetric reactions [2-12]. Moreover, in recent years, much attention has been devoted to the synthesis of new neutral ditopic salen receptors able to simultaneously bind chiral ammonium cations and their counteranions [13]. Generally, in addition to electrostatic interactions, hydrogen bonding and dispersive non bonding $\pi-\pi$ interactions cooperate for binding affinity of intimate contact ion pair in organic solvents. 
In this paper we describe the synthesis of a novel 21-membered macrocyclic ligand incorporating a chiral salen moiety into a framework containing two biphenyl units. The salen moiety, due to the presence of two stereogenic carbon atoms in the diimine bridge, generates a chiral pocket which can coordinate metal cations (via imine nitrogen and oxygen phenolic atoms), such as uranyl or Mn. In particular the uranyl cation can be employed as a Lewis acidic site able to bind ion pairs [13] whereas the Mn metal center can act as a catalytic site in the enantioselective epoxidation of olefins [14].

\section{Results and Discussion}

Synthesis of the macrocyclic diimine ligand 5 is shown in Scheme 1. The bis(hydroxymethyl) dimer 1 was prepared in 40\% yield as reported elsewhere [15]. The selective alkylation of both phenolic hydroxyl groups with $\left(\mathrm{CH}_{3}\right)_{2} \mathrm{CH}\left(\mathrm{CH}_{2}\right)_{3} \mathrm{Br}$ in refluxing dry acetonitrile in the presence of one equivalent of potassium carbonate as a base, afforded 2, which was purified by column chromatography $(67 \%$ yield $)$.

Scheme 1. Synthesis of the macrocyclic salen 5 and its metal complexes.
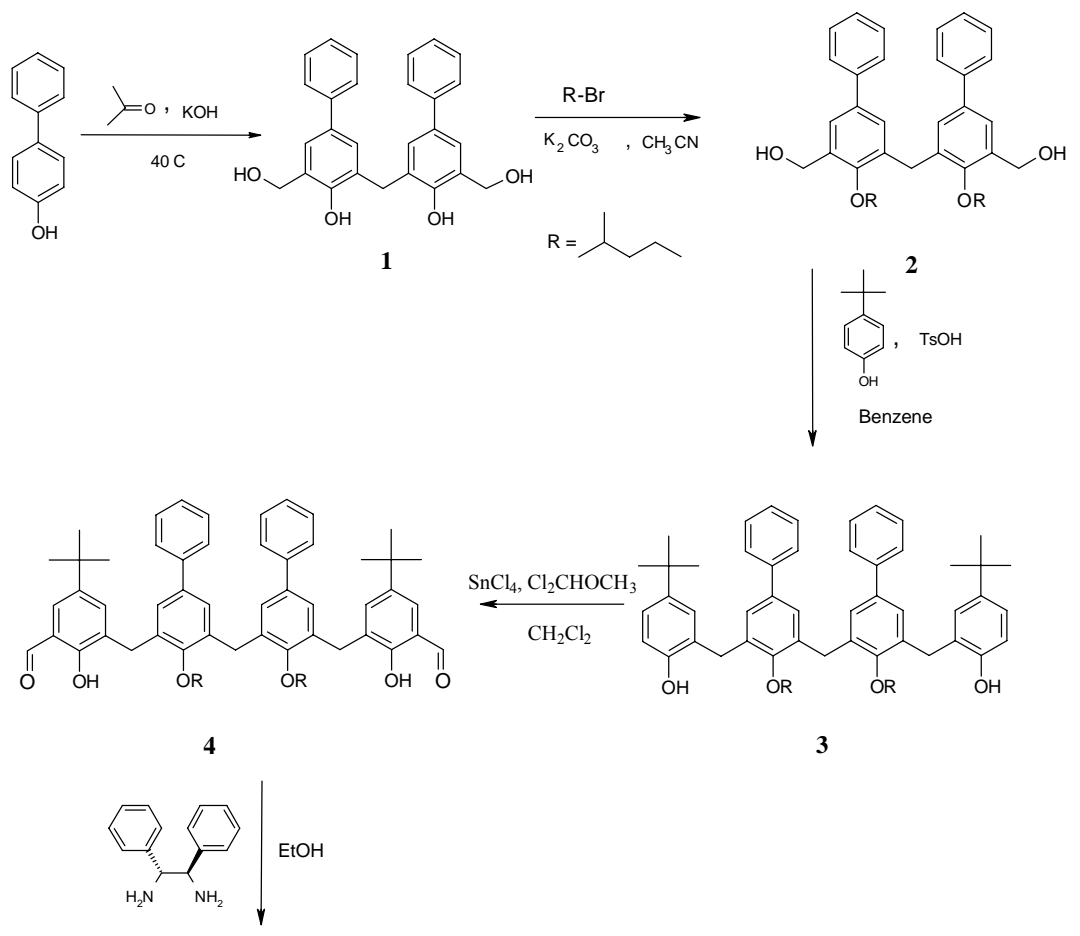

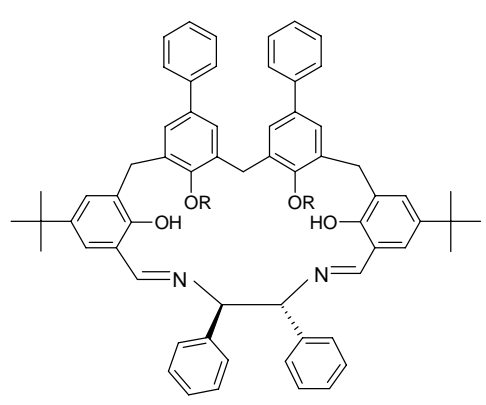

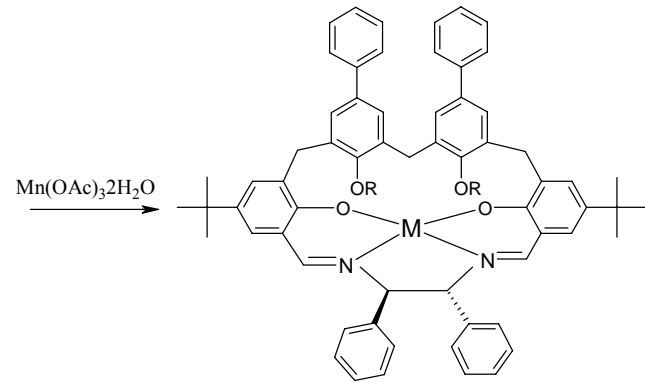

6

$\mathrm{M}=\mathrm{UO}_{2}, \mathrm{Mn}(\mathrm{III})$ 
Compound 2 was converted into 3 by acid-catalyzed condensation with a large excess of p-t-butylphenol in the presence of $\mathrm{TsOH}$ in benzene giving after column chromatography a white solid (76\% yield). The subsequent formylation [14] of 3 afforded dialdehyde 4 (70\% yield), which finally was cyclized with $(1 R, 2 R)$-1,2-diphenylethylenediamine in refluxing ethanol under high diluting conditions (40\% yield) to yield the macrocycle 5 .

The structural characterization of all new compounds 2-4 was achieved by ESI-MS measurements and $1 \mathrm{D}$ and 2D-NMR investigations. The ${ }^{1} \mathrm{H}$ - and ${ }^{13} \mathrm{C}-\mathrm{NMR}$ spectra of compounds $\mathbf{2}, \mathbf{3}$ and $\mathbf{4}$ in $\mathrm{CDCl}_{3}$ consist of relative simple patterns of resonances showing only one set of signals for each pair of identical groups. The formation of the macrocyclic ligand 5 was fully supported by the ESI-MS measurements $\left(\mathrm{m} / \mathrm{z}=1,077[\mathrm{MH}]^{+}\right)$.

The ${ }^{1} \mathrm{H}-\mathrm{NMR}$ spectrum of 5 in $\mathrm{CDCl}_{3}$ exhibits two sharp singlet signals at 8.42 and 4.73 ppm assigned to the azomethine $\mathrm{CH}=\mathrm{N}$ protons and the diimine bridge protons, respectively, while the broad singlet at $13.36 \mathrm{ppm}$ arise from phenolic hydroxylic protons. The AB system centered at $4.24 \mathrm{ppm}$ ( $\Delta \delta=0.05 \mathrm{ppm}, J=16.9 \mathrm{~Hz}$ ) was assigned to the diasterotopic methylene protons located between the two $p$-phenyl-phenoxy groups. The AB system centered at $4.12 \mathrm{ppm}(\Delta \delta=0.22 \mathrm{ppm}, J=15.8 \mathrm{~Hz})$ integrating for four protons was easily attributed to the remaining two methylene groups. Aromatic protons resonate in the appropriate low field region and alkyl ether substituents gave one set of the expected multiplets (1-2 ppm). This simple spectrum, supported by the T-ROESY data (Figure 1a), indicates that the ligand assumes a $\mathrm{C} 1$ averaged symmetric cyclic structure in a non-interconvertible cone conformation ensured by the presence of sufficiently bulky 4-methylbutyl groups at the lower rim. In agreement with NMR spectroscopic data, MMFFs force field [16] calculation produced the computed lowest-energy structure of macrocycle 5 (Figure 1b).

Figure 1. (a) ${ }^{1} \mathrm{H}-\mathrm{NMR}\left(500 \mathrm{MHz}, \mathrm{CDCl}_{3}, 300 \mathrm{~K}\right)$ T-ROESY map and (b) computed lowest-energy structure of macrocycle 5.

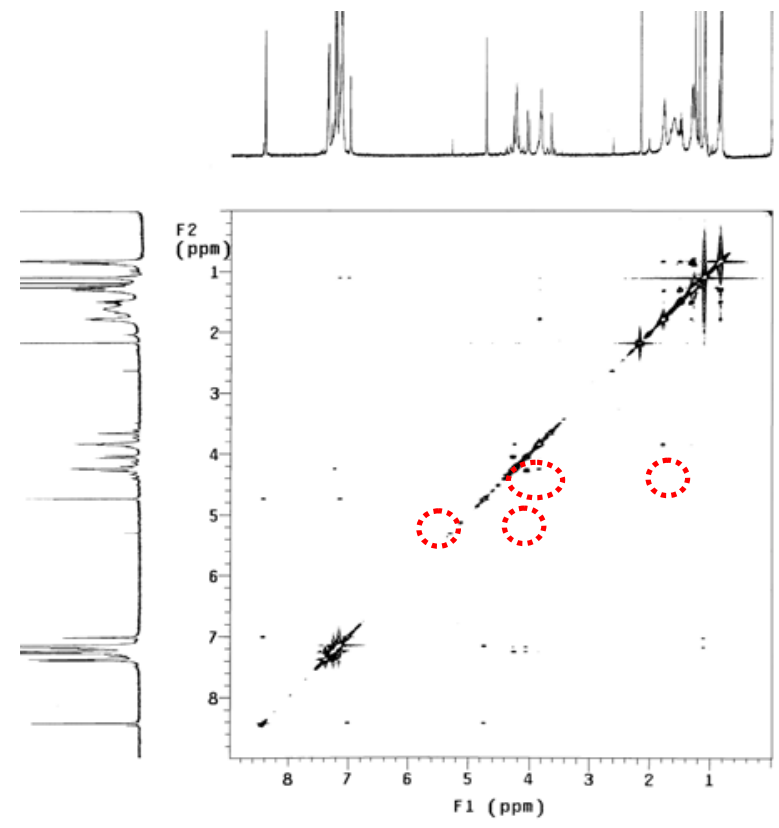

(a)

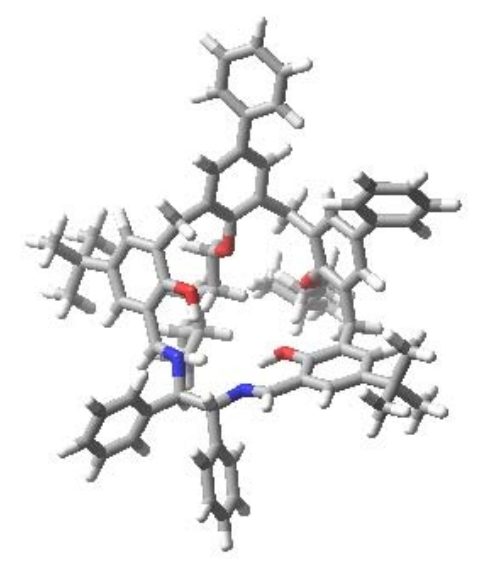

(b) 
Ligand 5 was utilized to prepare both $\mathrm{UO}_{2}(\mathrm{VI})$ and $\mathrm{Mn}(\mathrm{III})$ complexes 6-UO- $\mathbf{O}_{2}$ and 6-Mn (Scheme 1). To a stirred solution of ligand 5 in EtOH, solid $(\mathrm{AcO})_{2} \mathrm{UO}_{2} \cdot 2 \mathrm{H}_{2} \mathrm{O}$ or $\mathrm{Mn}(\mathrm{AcO})_{3} \cdot 2 \mathrm{H}_{2} \mathrm{O}$ respectively was added. The mixtures were allowed to stir overnight at room temperature and were monitored by TLC. Evaporation of the solvent gave a residue, which was dissolved in $\mathrm{CH}_{2} \mathrm{Cl}_{2}$, filtered and concentrated to produce the uranyl or Mn complex in a nearly quantitative yield. ESI-MS spectra confirmed the formation of the mono-metallic complexes.

Structural information on the uranyl(VI) complex $\left(\mathbf{6}-\mathbf{U O}_{2}\right)$, in solution, were obtained from $1 \mathrm{D}$ and

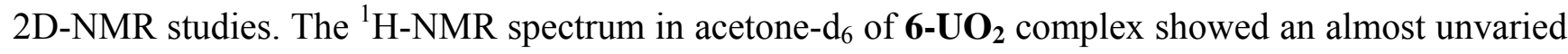
pattern of signals with respect to the free ligand, even considering the expected broadening and downfield shift of the resonances arising from the protons close to the coordination site. The ROE relationships measured by the phase-sensitive T-ROESY spectrum in acetone- $\mathrm{d}_{6}$ are shown in Figure $2 \mathrm{a}$. The dipolar correlation contacts identified in the 2D map suggested that the symmetrical structure is maintained in solution upon metal complexation. The strong ROE correlations between aromatic protons signals and azomethine $\mathrm{CH}=\mathrm{N}$ protons, diimine bridge protons and $t$ - $\mathrm{Bu}$ groups allowed safe assignment of the partially overlapped signals of the aromatic protons system. Besides the characteristic bond-through ROE correlations in the aromatic moiety, no additional dipolar contacts were observed either between aromatics rings or between the aromatic protons and iso-hexyloxysubstituents. Interestingly, this finding ruled out any complex conformation where the diimine bridge phenyl rings were arranged in an almost anti-periplanar conformation. In agreement with MM calculated lowest energy structure, the complex adopts in solution a less hindered "disk-shaped" rather a "cup-like" shape (Figure 2b).

Figure 2. (a) ${ }^{1} \mathrm{H}-\mathrm{NMR}\left(500 \mathrm{MHz},\left(\mathrm{CD}_{3}\right)_{2} \mathrm{CO}, 300 \mathrm{~K}\right) \mathrm{T}-\mathrm{ROESY}$ map and (b) modelled structure of complex 6-UO $\mathbf{O}_{2}$.

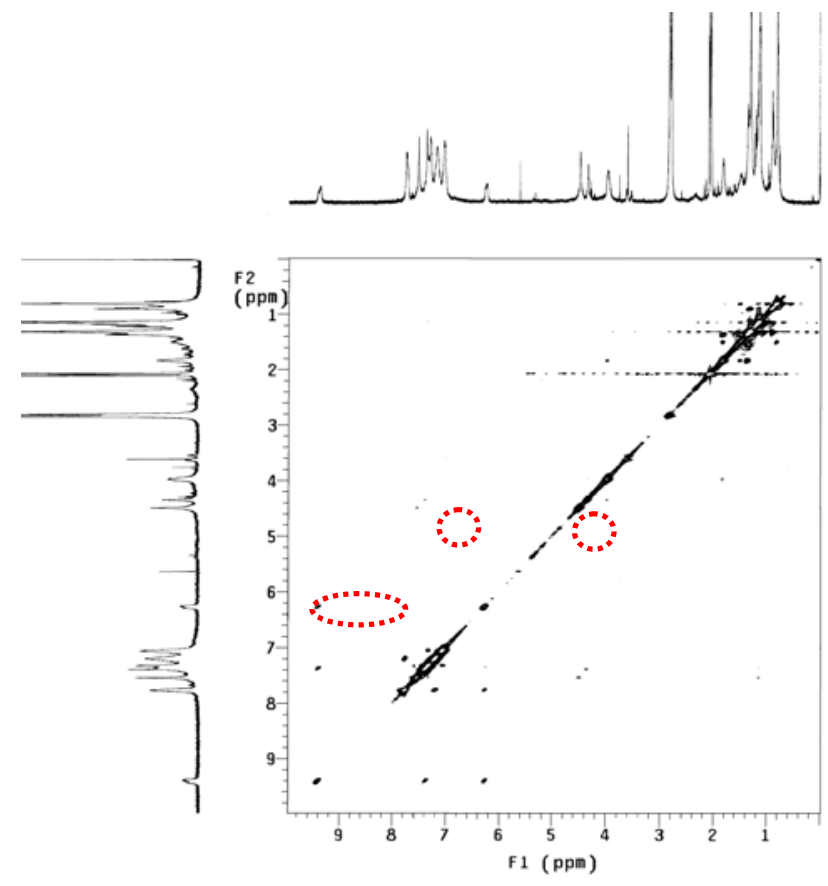

(a)

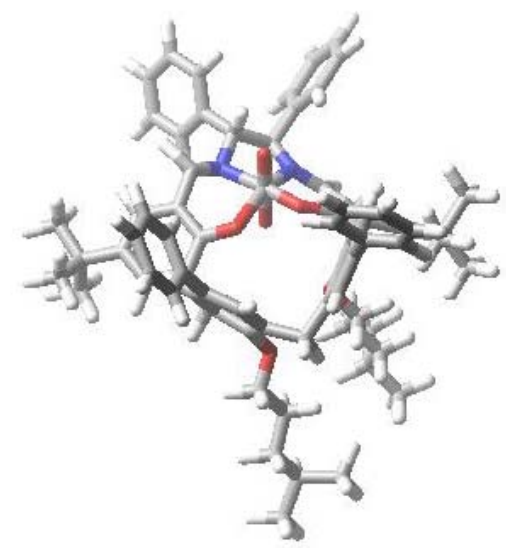

(b) 
The broadening of the lines of the ${ }^{1} \mathrm{H}$ spectrum might envisage the flipping motion of the salicylaldehyde framework already observed for uranyl salophen and salen complexes [13,17-19]. In order to enlighten on possible exchanging process occurring in solution, the proton signals of the uranyl complex were monitored carefully at lower temperature (Figure 3). As the temperature was lowered all the signals progressively broadened. At $193 \mathrm{~K}$ the signals of $\mathrm{CH}=\mathrm{N}$ and diimine bridge protons were no longer visible and methylene protons located between the macrocycle aromatic rings coalesced into an unresolved envelope. Further cooling to $183 \mathrm{~K}$ did not produce additional detectable changes in the spectral profile neither new signals could be revealed. Only trivial modifications were observed in the range $183-213 \mathrm{~K}$ in the aromatic spectra, easily attributed to slower bi-phenyl rotation.

Figure 3. Variable temperature ${ }^{1} \mathrm{H}$ NMR spectrum of 6-UO $\mathbf{O}_{2}$ complex $(500 \mathrm{MHz}$, $\left.\left(\mathrm{CD}_{3}\right)_{2} \mathrm{CO}\right)$ at relevant temperatures.

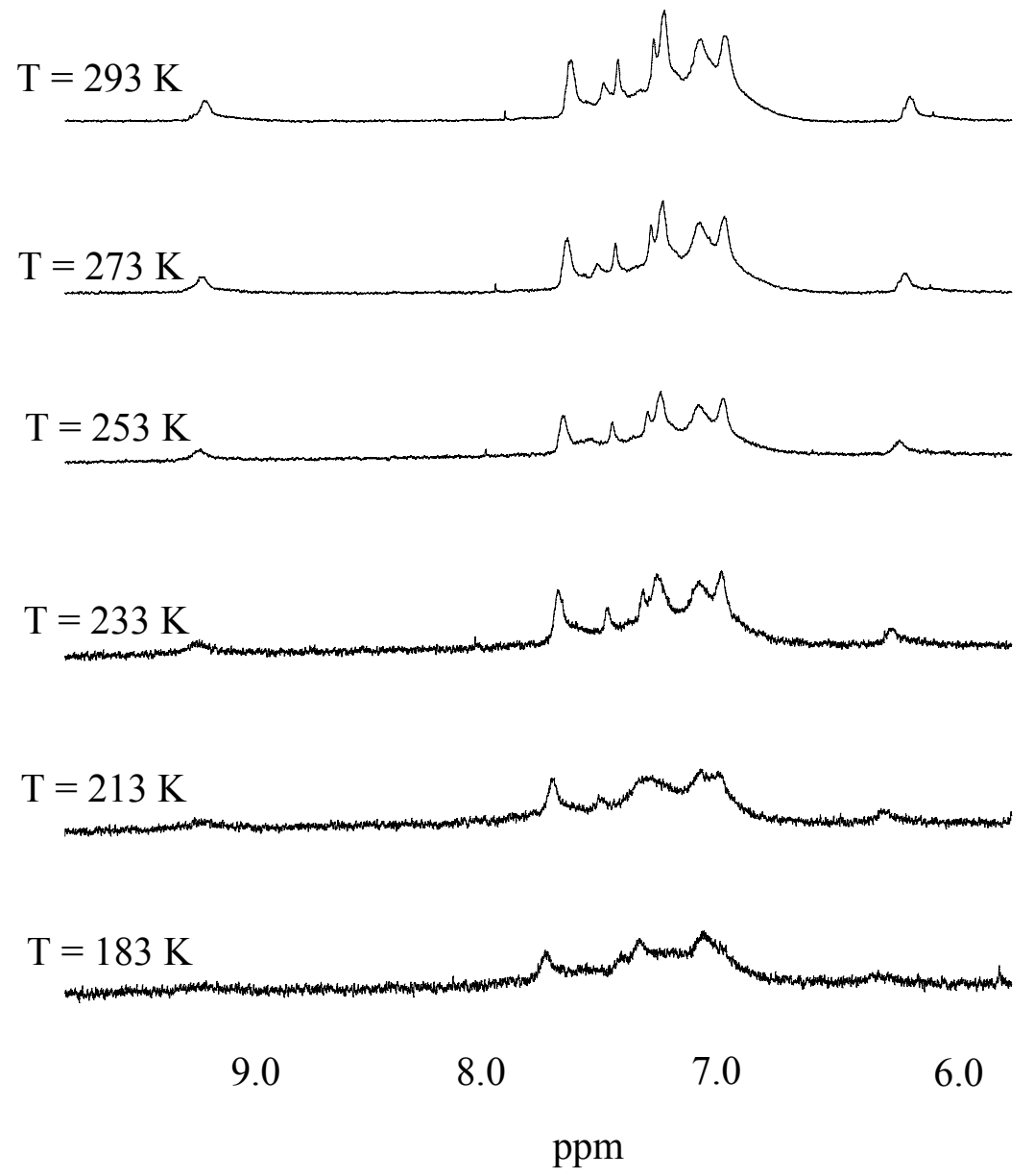

The 6-Mn complex was characterised by ESI mass spectroscopy $\left(\mathrm{m} / \mathrm{z}=1129[\mathrm{M}]^{+}\right)$. The catalytic ability of 6-Mn was tested in the epoxidation reactions of some prochiral alkenes. The reactions were performed in $\mathrm{CH}_{2} \mathrm{Cl}_{2} / \mathrm{H}_{2} \mathrm{O}$ at $25^{\circ}$ using $\mathrm{NaClO}$ as oxygen donor and 4-phenyl-pyridine $\mathrm{N}$-oxide (4PPNO) as coligand. Enantiomeric excess values for the formation of epoxides were determined by capillary GLC analysis employing chiral columns [14] for 1,2-dihydronaphthalene, and by ${ }^{1} \mathrm{H}-\mathrm{NMR}$ in the presence of $\mathrm{Eu}(+)(\mathrm{hfc})_{3}$ reagent shift for chromene derivatives epoxides. 
The results are reported in Table 1 . The reactions were allowed to proceed overnight $(24 \mathrm{~h})$ reaching $80 \%-90 \%$ completion (entries 2-4) and quantitative yield in the corresponding epoxides (entries 1-5).

Table 1. Enantioselective Epoxidation reactions of Alkenes with $\mathrm{NaClO}$ catalyzed by 6-Mn in $\mathrm{CH}_{2} \mathrm{Cl}_{2} / \mathrm{H}_{2} \mathrm{O}$ at $25^{\circ} \mathrm{C}$. ${ }^{\text {a }}$

Conv. (\%)
Yield (\%)

The observed effect of the coligand (compare entries 1 and 2) and the absolute configuration of the cis-epoxides were in agreement with literature data [14,20-22].

Previously reported studies indicated that the dissymmetry of diimine bridge should favour the approaching of the si enantioface of the alkene towards the Mn-oxo site of chiral salen catalysts [14]. The observed ee values for the alkenes reported in Table 1 are in line with this finding. However the degree of enantioselectivity displayed is moderate. In order to try to understand the observed behaviour, molecular mechanics calculations were performed on the complexes. Figure 4 shows the attack to the catalyst of both re and si face of the dihydronaphthalene. Very small differences were found for calculated energies $\left(<5 \mathrm{~kJ} \mathrm{~mol}^{-1}\right)$ suggesting that the attack pathways by the re and si face are energetically equivalent. Similar results were obtained in all the modelled structures of the examined alkenes and the catalyst. This behaviour might be ascribed to the presence of the biphenyl rings, which can undergo atropoisomerization and then can adapt their spatial position to the approaching guest, favouring therefore $\pi-\pi$ interactions with the aromatic framework of the alkene regardless of the alkene exposed face. 
Figure 4. Computer optimized structures concerning the re (a) and si (b) face attack of dihydronaphthalene to the 6-Mn catalyst.

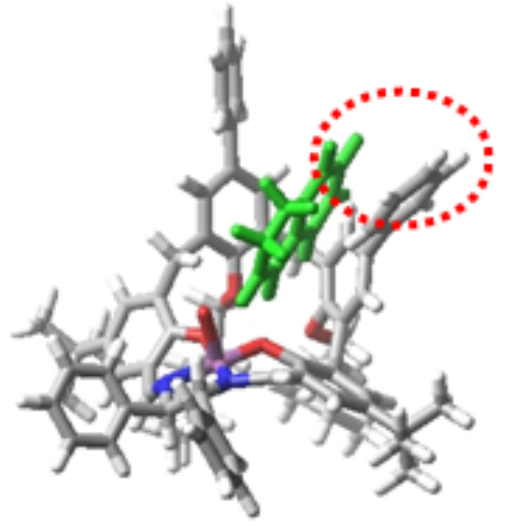

(a)

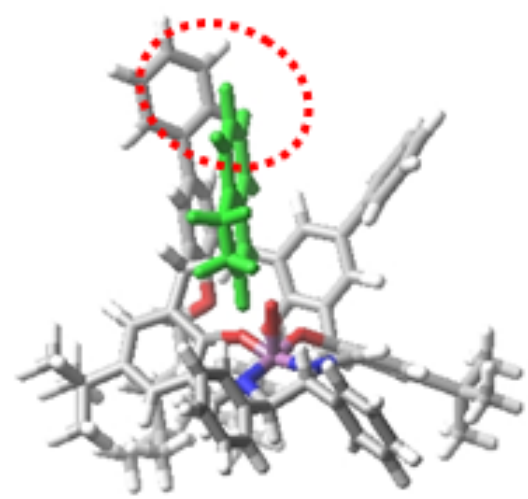

(b)

\section{Experimental}

\subsection{General}

Melting points were determined on a Kofler hot stage apparatus and are uncorrected. The NMR experiments were carried out at $27{ }^{\circ} \mathrm{C}$ on a $500 \mathrm{MHz}$ spectrometer $\left({ }^{1} \mathrm{H}\right.$ at $499.88 \mathrm{MHz},{ }^{13} \mathrm{C}-\mathrm{NMR}$ at 125.7 MHz) equipped with pulse field gradient module ( $\mathrm{Z}$ axis) and a tunable $5 \mathrm{~mm}$ inverse detection probe. The chemical shifts (ppm) were referenced to TMS as internal standard. Gas chromatographic analyses of the reaction mixtures were carried out on a gas chromatograph equipped with a flame ionization detector and program capability on a DMePeBETACDX (1,2-dihydronaphthalene) $(25 \mathrm{~m} \times 0.25 \mathrm{~mm}$ ID, $0.25 \mu \mathrm{m}$ film) against an internal standard ( $n$-decane). ESI mass spectra were obtained by employing an ESI-MS spectrometer equipped with an ion trap analyzer. The absolute configuration of $(1 R, 2 S)$-1,2-epoxy-1,2,3,4-tetrahydronaphthalene, (3R,4R)-3,4-epoxy-6-methoxy-2-2dimethyl chromene, $(3 R, 4 R)$-3,4-epoxy-6-cyano-2-2-dimethylchromene and (3R,4R)-3,4-epoxy-6-nitro-22-dimethylchromene were determined by measuring the optical rotation with a polarimeter. Measurements of optical rotation gave $[\alpha]_{\mathrm{D}}{ }^{20}=+17.5\left(c=0.20, \mathrm{CHCl}_{3}\right)$ for 1,2-epoxy-1,2,3,4tetrahydronaphthalene, $[\alpha]_{\mathrm{D}}{ }^{20}=+10.8\left(c=1.1, \mathrm{CHCl}_{3}\right)$ for 3,4-epoxy-6-methoxy-2-2dimethylchromene, $[\alpha]_{\mathrm{D}}{ }^{20}=+34.3\left(c=0.94, \mathrm{CHCl}_{3}\right)$ for 3,4-epoxy-6-cyano-2-2-dimethylchromene, $[\alpha]_{\mathrm{D}}{ }^{20}=+11.1\left(c=0.1, \mathrm{CHCl}_{3}\right)$ for 3,4-epoxy-6-nitro-2-2-dimethylchromene. Absolute configurations were assigned by comparison of the measured $[\alpha]_{\mathrm{D}}{ }^{20}$ values with those reported in the literature $[14,23]$. Commercial reagents were used as received without further purification unless otherwise noted. 6-Cyano-2,2-dimethylchromene, 6-nitro-2,2-dimethylchromene and 6-methoxy-2,2-dimethylchromene were synthesized by the Bergmann and Gericke procedure [24]. Dichloromethane was freshly distilled from calcium hydride before use.

\subsection{General Procedures for the Epoxidation Reactions}

To a stirred solution of alkene $(0.35 \mathrm{mmol})$, catalyst $(0.0175 \mathrm{mmol})$ and 4-phenylpyridine- $N$-oxide (4-PPNO, $0.175 \mathrm{mmol}$ ) in $\mathrm{CH}_{2} \mathrm{Cl}_{2}(2.5 \mathrm{~mL})$, kept in a round bottom flask and maintained at $25^{\circ} \mathrm{C}$ in a 
thermostatic bath, buffered bleach $\left(0.35 \mathrm{mmol}\right.$, buffered to $\mathrm{pH}=11.2$ with $\left.0.05 \mathrm{M} \mathrm{Na}_{2} \mathrm{HPO}_{4}\right)$ is added. The course of the reaction was monitored by GC. After $24 \mathrm{~h}$, the phases were separated, and the aqueous layer was extracted with $\mathrm{CH}_{2} \mathrm{Cl}_{2}$. The combined organic phases were dried over $\mathrm{Na}_{2} \mathrm{SO}_{4}$ and concentrated. The crude product was purified by $\mathrm{PLC}\left(\mathrm{SiO}_{2}\right)$.

3-[3-(Hydroxymethyl)-5-phenylsalicyl]-5-phenyl-2-hydroxybenzyl alcohol (1). Compound 1 was prepared according to literature procedure [15]: a mixture of $p$-phenylphenol (30 g, $0.18 \mathrm{~mol})$ and formaldehyde $37 \%(150 \mathrm{~mL}, 1.8 \mathrm{~mol})$ was cooled in an ice bath, treated slowly with $\mathrm{KOH}(20.4 \mathrm{~g}$, $0.36 \mathrm{~mol})$, and then stirred for 7 days at $40{ }^{\circ} \mathrm{C}$. Crystallization from $\mathrm{CH}_{3} \mathrm{OH}$ yielded $30 \mathrm{~g}(40 \%)$ of 1 as a white powder: mp $127-128{ }^{\circ} \mathrm{C} .{ }^{1} \mathrm{H}-\mathrm{NMR}$ (acetone- $\left.\mathrm{d}_{6}\right) \delta \mathrm{ppm}: 7.55 \mathrm{ArH}(\mathrm{d}, 6 \mathrm{H}, J=7 \mathrm{~Hz}) 7.37 \mathrm{ArH}(\mathrm{t}$, $4 \mathrm{H}, J=7.4 \mathrm{~Hz}$, 7.32 $\mathrm{ArH}(\mathrm{s}, 2 \mathrm{H}), 7.24 \mathrm{ArH}(\mathrm{t}, 2 \mathrm{H}, J=7.4 \mathrm{~Hz}), 4.90 \mathrm{CH}_{2} \mathrm{OH}(\mathrm{s}, 4 \mathrm{H}), 4.11 \mathrm{CH}_{2}(\mathrm{~s}, 2 \mathrm{H})$, $3.30 \mathrm{OH}$ (br, 2H). ESI-MS : m/z $435[\mathrm{M} \mathrm{Na}]^{+}$.

3-[2-Isohexyloxy-3-(hydroxymethyl]-5-phenyl-2-isohexyloxybenzyl alcohol (2). A stirred mixture of 1 (5.43 g, $13 \mathrm{mmol})$, 1-bromo-4-methylpentane $(10 \mathrm{~g}, 61 \mathrm{mmol})$ and anhydrous $\mathrm{K}_{2} \mathrm{CO}_{3}(4.2 \mathrm{~g}$, $30 \mathrm{mmol})$ in dry MeCN (200 mL) was refluxed for $24 \mathrm{~h}$. After filtration and evaporation of the solvent, the residue was dissolved in $\mathrm{CH}_{2} \mathrm{Cl}_{2}$. The organic layer was washed with water, dried over anhydrous $\mathrm{Na}_{2} \mathrm{SO}_{4}$ and concentrated. Crystallization from $\mathrm{CH}_{2} \mathrm{Cl}_{2} / \mathrm{n}$-hexane yielded $5.1 \mathrm{~g}(67 \%)$ of 2 as a white powder: mp 90-91 ${ }^{\circ} \mathrm{C} .{ }^{1} \mathrm{H}-\mathrm{NMR}\left(\mathrm{CDCl}_{3}\right) \delta \mathrm{ppm}$ : 7.47 $\mathrm{ArH}(\mathrm{m}, 6 \mathrm{H}), 7.36 \mathrm{ArH}(\mathrm{t}, 4 \mathrm{H}, J=7.5 \mathrm{~Hz}), 7.28$ $\operatorname{ArH}(\mathrm{m}, 4 \mathrm{H}), 4.81 \mathrm{CH}_{2} \mathrm{OH}(\mathrm{d}, 4 \mathrm{H}, J=6 \mathrm{~Hz}), 4.17 \mathrm{CH}_{2}(\mathrm{~s}, 2 \mathrm{H}), 3.86 \mathrm{OCH}_{2}(\mathrm{t}, 4 \mathrm{H}, J=6.5 \mathrm{~Hz}), 2.19$ $\mathrm{CH}_{2} \mathrm{OH}(\mathrm{t}, 2 \mathrm{H}, J=6 \mathrm{~Hz}), 1.82 \mathrm{OCH}_{2} \mathrm{CH}_{2}(\mathrm{~m}, 4 \mathrm{H}), 1.59\left(\mathrm{CH}_{3}\right)_{2} \mathrm{CH}(\mathrm{m}, 2 \mathrm{H}), 1.35 \mathrm{OCH}_{2} \mathrm{CH}_{2} \mathrm{CH}_{2}(\mathrm{~m}, 4 \mathrm{H})$, $0.92 \mathrm{CH}_{3}(\mathrm{~d}, 12 \mathrm{H}, J=7 \mathrm{~Hz}) .{ }^{13} \mathrm{C}-\mathrm{NMR}\left(\mathrm{CDCl}_{3}\right) \delta \mathrm{ppm}: 155.93,153.30,150.94,142.79,140.59$, 138.07, 133.51, 128.62, 128.07, 127.76, 127.05, 127.02, 126.97, 126.30, 126.22, 124.20, 75.67, 63.68, 35.01, 33.99, 31.55, 29.70, 27.99, 27.92, 22.54; ESI-MS : m/z $603[\mathrm{MNa}]^{+}$. Anal. Calcd for $\mathrm{C}_{39} \mathrm{H}_{48} \mathrm{O}_{4}$ : C, 80.69; H, 8.28. Found: C, 80.98; H, 8.16.

2-[3-[3-(5-tert-Butylsalicyl)-5-phenyl-2-isohexyloxybenzyl]-5-phenyl-2-isohexyloxybenzyl]-4-tertbutylphenol (3). A stirred mixture of $2(5.0 \mathrm{~g}, 9 \mathrm{mmol})$, p-tert-butylphenol (13 g, $86 \mathrm{mmol})$ and $p$ toluenesulfonic acid $(370 \mathrm{mg}, 0.44 \mathrm{mmol})$ in benzene $(30 \mathrm{~mL})$ was refluxed for $24 \mathrm{~h}$. After evaporation of the solvent and remove excess of p-tert-butylphenol with sublimate under vacuum at $115{ }^{\circ} \mathrm{C}$ the residue was dissolved in $\mathrm{CH}_{2} \mathrm{Cl}_{2}$. The organic layer was washed with water, dried over anhydrous $\mathrm{Na}_{2} \mathrm{SO}_{4}$, concentrated and purified by column chromatography $\left(\mathrm{SiO}_{2}\right.$, eluent $n$-hexane/AcOEt 7:1, v/v) to give (3) $(5.5 \mathrm{~g}, 76 \%)$ as a white powder: mp 99-100 ${ }^{\circ} \mathrm{C} .{ }^{1} \mathrm{H}-\mathrm{NMR}\left(\mathrm{CDCl}_{3}\right) \delta \mathrm{ppm}$ : 7.40-7.12 $\mathrm{ArH}$ $(\mathrm{m}, 18 \mathrm{H}), 6.78 \mathrm{ArH}(\mathrm{d}, 2 \mathrm{H}, J=8.5 \mathrm{~Hz}) 4.19 \mathrm{CH}_{2}(\mathrm{~s}, 2 \mathrm{H}), 3.98 \mathrm{OCH}_{2}(\mathrm{t}, 2 \mathrm{H}, J=6.5 \mathrm{~Hz}), 3.95 \mathrm{CH}_{2}(\mathrm{~s}$, $4 \mathrm{H}), 1.90 \mathrm{OCH}_{2} \mathrm{CH}_{2}(\mathrm{~m}, 4 \mathrm{H}), 1.56\left(\mathrm{CH}_{3}\right)_{2} \mathrm{CH}(\mathrm{m}, 2 \mathrm{H}), 1.35 \mathrm{OCH}_{2} \mathrm{CH}_{2} \mathrm{CH}_{2}(\mathrm{~m}, 4 \mathrm{H}), 1.29 \mathrm{CCH}_{3}(\mathrm{~s}$, $18 \mathrm{H}), 0.92 \mathrm{CH}_{3}(\mathrm{~d}, 12 \mathrm{H}, J=7 \mathrm{~Hz}) .{ }^{13} \mathrm{C}-\mathrm{NMR}\left(\mathrm{CDCl}_{3}\right) \delta \mathrm{ppm:} \mathrm{152.95,} \mathrm{152.25,} \mathrm{142.97,} \mathrm{140.50,} \mathrm{138.38,}$ $133.62,133.39,128.61,128.10,127.77,127.12$, 127.02, 126.39, 125.62, 125.11, 116.06, 114.73, 75.88, 34.9, 33.98, 32.25, 31.62, 31.52, 29.98, 27.88, 22.46; ESI-MS: m/z $867[\mathrm{MNa}]^{+}$. Anal. Calcd for $\mathrm{C}_{59} \mathrm{H}_{72} \mathrm{O}_{4}:$ C, 83.89; H, 8.53. Found: C, 80.87; H, 8.59.

3-[3-[3-[3-(Formyl)-(5-tert-butylsalicyl)]-5-phenyl-2-isohexyloxybenzyl]-5-phenyl-2-isohexyloxybenzyl]-5-tert-butyl-salicylaldehyde (4). To a chilled solution of 3 (1.12 g, $1.32 \mathrm{mmol})$ in dry $\mathrm{CH}_{2} \mathrm{Cl}_{2}$ (50 mL) was added $\mathrm{Cl}_{2} \mathrm{CHOCH}_{3}(2.34 \mathrm{~mL}, 26.4 \mathrm{mmol})$ under $\mathrm{N}_{2}$. A $1 \mathrm{M}$ solution of $\mathrm{SnCl}_{4}$ in $\mathrm{CH}_{2} \mathrm{Cl}_{2}$ 
(2.64 $\mathrm{mL}, 2.64 \mathrm{mmol}$ ) was then added and after 20 minutes the reaction was stopped with $1 \mathrm{M} \mathrm{HCl}$ [14]. The mixture was washed with a saturated aqueous solution of $\mathrm{NaHCO}_{3}$ and then with water, and dried over anhydrous $\mathrm{Na}_{2} \mathrm{SO}_{4}$. The solvent was removed under reduced pressure and the resulting oil was purified by column chromatography $\left(\mathrm{SiO}_{2}\right.$, eluent: $n$-hexane/acetone $\left.6: 1\right)$ to give 4 as a white solid. (0.83 g, 70\%). ${ }^{1} \mathrm{H}-\mathrm{NMR}\left(\mathrm{CDCl}_{3}\right) \delta \mathrm{ppm}: 11.18 \mathrm{ArOH}(\mathrm{s}, 2 \mathrm{H}), 9.88 \mathrm{CHO}(\mathrm{s}, 2 \mathrm{H})$, 7.50-7.18 ArH (m, 18H), 4.22 $\mathrm{CH}_{2}(\mathrm{~s}, 2 \mathrm{H}), 4.12 \mathrm{CH}_{2}(\mathrm{~s}, 4 \mathrm{H}), 3.84 \mathrm{OCH}_{2}(\mathrm{t}, 4 \mathrm{H}, J=6.5 \mathrm{~Hz}), 1.90$ $\mathrm{OCH}_{2} \mathrm{CH}_{2}(\mathrm{~m}, 4 \mathrm{H}), 1.59\left(\mathrm{CH}_{3}\right)_{2} \mathrm{CH}(\mathrm{m}, 2 \mathrm{H}), 1.35 \mathrm{OCH}_{2} \mathrm{CH}_{2} \mathrm{CH}_{2}(\mathrm{~m}, 4 \mathrm{H}), 1.26 \mathrm{CCH}_{3}(\mathrm{~s}, 18 \mathrm{H}), 0.91$ $\mathrm{CH}_{3}\left(\mathrm{~d}, 12 \mathrm{H}, \mathrm{J}=7 \mathrm{~Hz}\right.$ ). MS-ESI: $\mathrm{m} / \mathrm{z} 923[\mathrm{MNa}]^{+}$. Anal. Calcd for $\mathrm{C}_{61} \mathrm{H}_{72} \mathrm{O}_{6}: \mathrm{C}, 81.33 ; \mathrm{H}$, 8.0. Found: C, 81.74; H, 8.41.

Condensation of 3-[3-[3-[3-(formyl)-(5-tert-butylsalicyl)]-5-phenyl-2-isohexyloxybenzyl]-5-phenyl-2isohexyloxybenzyl]-5-tert-butyl- salicylaldehyde with (1R,2R)-diphenylethylendiamine (5). Solutions of $4(0.27 \mathrm{~g} 0.3 \mathrm{mmol})$ in $\mathrm{EtOH}(27 \mathrm{~mL})$ and $(1 R, 2 R)$-1,2-diphenylethylendiamine $(0.064 \mathrm{~g}$, $0.3 \mathrm{mmol})$, in EtOH (14 mL), were dropped separately but synchronously from two dropping funnels into boiling abs EtOH $(200 \mathrm{~mL})$ under rapid stirring. The reaction mixture was refluxed for an additional $24 \mathrm{~h}$, and cooled. After removal of the solvent, the crude product was column chromatographed $\left(\mathrm{SiO}_{2}\right.$, eluent $n$-hexane/acetone $\left.6: 1, \mathrm{v} / \mathrm{v}\right)$ to afford $5(0.13 \mathrm{~g}, 40 \%) .{ }^{1} \mathrm{H}-\mathrm{NMR}\left(\mathrm{CDCl}_{3}\right)$ $\delta$ ppm: 13.36 $\mathrm{ArOH}(\mathrm{s}, 2 \mathrm{H}), 8.42 \mathrm{CH}=\mathrm{N}(\mathrm{s}, 2 \mathrm{H}), 7.37-7.00 \mathrm{ArH}(\mathrm{m}, 26 \mathrm{H}), 4.73 \mathrm{CH}-\mathrm{N}(\mathrm{s}, 2 \mathrm{H}), 4.26 \mathrm{CH}_{2}$ $(\mathrm{d}, 2 \mathrm{H}, J=15 \mathrm{~Hz}), 4.23(\mathrm{~s}, 2 \mathrm{H}), 4.04 \mathrm{CH}_{2}(\mathrm{~d}, 4 \mathrm{H} \mathrm{J}=15 \mathrm{~Hz}), 3.83 \mathrm{OCH}_{2}(\mathrm{t}, 4 \mathrm{H}, J=6.5 \mathrm{~Hz}), 1.79$ $\mathrm{OCH}_{2} \mathrm{CH}_{2}(\mathrm{~m}, 4 \mathrm{H}), 1.50\left(\mathrm{CH}_{3}\right)_{2} \mathrm{CH}(\mathrm{m}, 2 \mathrm{H}), 1.30 \mathrm{OCH}_{2} \mathrm{CH}_{2} \mathrm{CH}_{2}(\mathrm{~m}, 4 \mathrm{H}), 1.1 \mathrm{CCH}_{3}(\mathrm{~s}, 18 \mathrm{H}), 0.8 \mathrm{CH}_{3}$ $(\mathrm{d}, 12 \mathrm{H}, J=7 \mathrm{~Hz}) .{ }^{13} \mathrm{C}-\mathrm{NMR}\left(\mathrm{CDCl}_{3}\right) \delta \mathrm{ppm}: 166.76,156.722,155.71,141.14,140.94,139.56$, $136.54,134.30,133.85,131.09,128.84,128.49,128.25,128.00,127.71,127.51,127.39,126.93$, $126.58,126.44,117.55,35.17,33.80,31.39,31.31,30.94,29.31,28.35,27.96,22.55 ;$ ESI-MS: m/z $1077[\mathrm{MH}]^{+}$. Anal. Calcd for $\mathrm{C}_{75} \mathrm{H}_{84} \mathrm{~N}_{2} \mathrm{O}_{4}$ : C, 83.64; H, 7.81; N, 2.60. Found: C, 83.31; H, 7.86; N, 2.62.

Uranyl complex $\left(\mathbf{6}-\mathrm{UO}_{2}\right)$. $(\mathrm{AcO})_{2} \mathrm{UO}_{2} \cdot 2 \mathrm{H}_{2} \mathrm{O}(10 \mathrm{mg}, 0.025 \mathrm{mmol})$ was added as a solid to a stirred solution of the ligand 5 ( $20 \mathrm{mg}, 0.02 \mathrm{mmol})$ in $\mathrm{MeOH}(10 \mathrm{~mL})$. The mixture was allowed to stir overnight at room temperature and was monitored by TLC (eluent: $20 \%$ acetone in $n$-hexane). The solvent was removed on a rotary evaporator under vacuum and the residue was dissolved in $\mathrm{CH}_{2} \mathrm{Cl}_{2}$, filtered and concentrated to produce the pertinent uranyl complex in a nearly quantitative yield. ${ }^{1} \mathrm{H}-\mathrm{NMR}$ (acetone $\mathrm{d}_{6}$ ) $\delta$ ppm: 9.41 CH=N (br, 2H), 7.79-7.08 $\mathrm{ArH}(\mathrm{m}, 26 \mathrm{H}), 6.23 \mathrm{CH}-\mathrm{N}(\mathrm{s}, 2 \mathrm{H}), 4.52$ $\mathrm{CH}_{2}(\mathrm{~s}, 2 \mathrm{H}),, 4.28 \mathrm{CH}_{2}(\mathrm{~s}, 4 \mathrm{H}), 3.96 \mathrm{OCH}_{2}(\mathrm{bt}, 4 \mathrm{H}), 1.82 \mathrm{OCH}_{2} \mathrm{CH}_{2}(\mathrm{~s}, 4 \mathrm{H}), 1.65\left(\mathrm{CH}_{3}\right)_{2} \mathrm{CH}(\mathrm{m}, 2 \mathrm{H})$, $1.35 \mathrm{OCH}_{2} \mathrm{CH}_{2} \mathrm{CH}_{2}(\mathrm{~m}, 4 \mathrm{H}), 1.26 \mathrm{CCH}_{3}(\mathrm{~s}, 18 \mathrm{H}), 0.91 \mathrm{CH}_{3}(\mathrm{~d}, 12 \mathrm{H}, J=7 \mathrm{~Hz})$. ESI-MS: m/z 1345 $[\mathrm{MH}]^{+}$. Anal. Calcd for $\mathrm{C}_{75} \mathrm{H}_{82} \mathrm{~N}_{2} \mathrm{O}_{6} \mathrm{U}: \mathrm{C}, 66.96 ; \mathrm{H}, 6.10 ; \mathrm{N}, 2.08$. Found: C, 66.73; H, 6.13; N, 2.10.

[Mn(III)(L)] complex (6-Mn). To a solution of the ligand 5 (65 mg, $0.06 \mathrm{mmol})$ in $\mathrm{CH}_{2} \mathrm{Cl}_{2}(8 \mathrm{~mL})$ was added a solution of $\mathrm{Mn}(\mathrm{OAc})_{3} \cdot 2 \mathrm{H}_{2} \mathrm{O}(16 \mathrm{mg}, 0.064 \mathrm{mmol})$ in EtOH $(8 \mathrm{~mL})$. The dark solution was allowed to stir overnight at room temperature and was monitored by TLC (eluent: $20 \%$ acetone in $n$-hexane). The solvent was removed under vacuum and the residue was dissolved in $\mathrm{CH}_{2} \mathrm{Cl}_{2}$, filtered and concentrated to produce the $\mathrm{Mn}(\mathrm{III})$ catalyst in a nearly quantitative yield. ESI-MS: $\mathrm{m} / \mathrm{z} 1129$ $[\mathrm{M}]^{+}$. Anal. Calcd for $\mathrm{C}_{77} \mathrm{H}_{85} \mathrm{MnN}_{2} \mathrm{O}_{6}: \mathrm{C}, 77.78 ; \mathrm{H}, 7.15 ; \mathrm{N}, 2.36$. Found: C, 77.68; H, 7.20; N, 2.40.4. 


\section{Conclusions}

We have synthesized a new macrocyclic chiral salen ligand and its $\mathrm{UO}_{2}$ and $\mathrm{Mn}(\mathrm{III})$ complexes. NMR studies of the (salen) $\mathrm{UO}_{2}$ complex are in agreement with $\mathrm{MM}$ calculated structures which indicate that the shallow conformation of the receptor cavity and, probably, the mobility of biphenyl rings are responsible of the observed moderate enantioselectivity. At any rate, the catalyst synthesized in this work represents the first example of salen derivatives combined with biphenyl units and the work is in progress to avoid the atropoisomerization of biphenyl units, in order to control more efficiently molecular recognition.

\section{Acknowledgements}

We thank University of Catania for financial support.

\section{References and Notes}

1. Steed, J.W.; Atwood, J.L. Supramolecular Chemistry; John Wiley \& Sons: Chichester, UK, 2000.

2. Katsuki, T. In Catalytic Asymmetric Synthesis, 2nd ed.; Ojima, I., Ed.; Wiley-VCH: New York, 2000; pp. 287-325

3. Katsuki, T. Catalytic asymmetric oxidations using optically active (salen) manganese(III) complexes as catalysts. Coord. Chem. Rev. 1995, 140, 189-214.

4. Katsuki, T. Some recent advances in metallosalen chemistry. Synlett 2003, 3, 281-297.

5. Irie, R.; Noda, K.; Ito, Y.; Matsumoto, N.; Katsuki, T. Catalytic asymmetric epoxidation of unfunctionalized olefins. Tetrahedron Lett. 1990, 31, 7345-7384.

6. Egami, H.; Irie, R.; Sakai, K.; Katsuki, T. Enantioselective epoxidation of conjugated Z-olefins with newly modified Mn(salen) complex. Chem. Lett. 2007, 36, 46-47.

7. Matsumoto, K.; Katsuki, T. In Asymmetric Synthesis-The Essentials, 2nd edition; Christmann, M., Bräse, S., Eds.; Wiley-VCH: Weinheim, Germany, 2008; pp. 123-127.

8. Zhang, W.; Loebach, J.L.; Wilson, S.R.; Jacobsen, E.N. Enantioselective epoxidation of unfunctionalized olefins catalyzed by salen manganese complexes. J. Am. Chem. Soc. 1990, 112, 2801-2803.

9. Jacobsen, E.N.; Zhang, W.; Guler, L.M. Electronic tuning of asymmetric catalysts. J. Am. Chem. Soc. 1991, 113, 6703-6704.

10. Jacobsen, E.N. Catalytic Asymmetric Synthesis; Ojima, I., Ed.; VCH: Weinheim, Germany, 1993; Chapter 4.2.

11. Palucki, M; Finney, N.S.; Pospisil, P. J.; Guler, M. L.; Ishida, T.; Jacobsen, E.N. The mechanistic basis for electronic effects on enantioselectivity in the (salen)Mn(III)-catalyzed epoxidation reaction. J. Am. Chem. Soc. 1998, 120, 948-954.

12. Yoon, T. P.; Jacobsen, E. N. Privileged chiral catalysis. Science 2003, 299, 1691-1693.

13. Amato, M.E.; Ballistreri, F.P.; Pappalardo, A.; Sciotto, D.; Tomaselli, G.A.; Toscano, R.M. Synthesis and conformational aspects of 20- and 40-memered macrocyclic mono and dinuclear uranyl complexes incorporating salen and (R)-BINOL units. Tetrahedron 2007, 63, 9751-9757. 
14. Amato, M.E.; Ballistreri, F.P.; Pappalardo, A.; Tomaselli, G.A.; Toscano, R.M.; Williams, D.J. Novel chiral $\mathrm{Mn}$ (III)-salen complexes containing a calix[4]-arene unit as enantioselective epoxidation catalysts. Eur. J. Org. Chem. 2005, 3562-3570.

15. Gutsche, C.D. Calixarenes. 8. Short, stepwise synthesis of p-phenylcalix[4]arene and p-phenyl-ptert-butylcalix[4]arene and derived products. J. Org. Chem. 1982, 47, 2713-2719.

16. Mohamadi, F.; Richards, N.G.J.; Guida, W.C.; Liskamp, R.; Lipton, M.; Caufield, C.; Chang, G.; Hendrickson, T.; Still,W.C. Macromodel - an integrated software system for modeling organic and bioorganic molecules using molecular mechanics. J. Comput. Chem. 1990, 11, 440-467.

17. Ballistreri, F.P.; Patti, A.; Pedotti, S.; Tomaselli, G.A.; Toscano, R.M. Synthesis of novel chiral "Salen-type" ferrocenyl ligands. Tetrahedron Asymmetry 2007, 18, 2377-2380.

18. Dalla Cort, A.; Gasparrini, F.; Lunazzi, L.; Mandolini, L.; Mozzanti, A.; Pasquini, C.; Pierini, M.; Rompietti, R.; Schiaffino, L. Stereomutations of atropisomers of sterically hindered salophen ligands. J. Org. Chem. 2005, 70, 8877-8883.

19. Dalla Cort, A.; Mandolini, L.; Calmieri, G.; Pasquini, C.; Schiaffino, L. Unprecedented detection of inherent chirality in uranyl-salophen complexes. Chem. Commun. 2003, 2178-2179.

20. Kureshy, R.I.; Khan, N.H.; Abdi, S.H.; Patel, S.T.; Iyer, P.K.; Jasra, R.V. Enantioselective epoxidation of chromenes using chiral $\mathrm{Mn}(\mathrm{III})$ salen catalysts with built-in phase-transfer capability. Tetrahedron Lett. 2002, 43, 2665-2668.

21. Xia, Q.H.; Ge, H.Q.; Ye, C.P.; Liu, Z.M.; Su, K.X. Advances in homogeneous and heterogeneous catalytic asymmetric epoxidation. Chem. Rev. 2005, 105, 1603-1662.

22. Shitama, H.; Katsuki, T. Synthesis of metal-(pentadentate-salen) complexes: asymmetric epoxidation with aqueous hydrogen peroxide and asymmetric cyclopropanation (salenH2: N,Nbis(salicylidene)ethylene-1,2-diamine). Chem. Eur. J. 2007, 13, 4849-4858.

23. Scheurer, A.; Mosset, P.; Spiegel, M.; Saalfrank, R.W. Reverse asymmetric catalytic epoxidation of unfunctionalized alkenes Tetrahedron 1999, 55, 1063-1078.

24. Bergmann, R.; Gericke, R. Synthesis and antihypertensive activity of 4-(1,2-dihydro-2-oxo-1pyridyl)-2H-1-benzopyrans and related compounds, new potassium channel activators. J. Med. Chem. 1990, 33, 492-504.

Sample Availability: Samples of the compounds are available from the authors.

(C) 2010 by the authors; licensee Molecular Diversity Preservation International, Basel, Switzerland. This article is an open-access article distributed under the terms and conditions of the Creative Commons Attribution license (http://creativecommons.org/licenses/by/3.0/). 